\title{
Transmediatisation of the Covid-19 crisis in Brazil: The emergence of (bio-/geo-)political repertoires of (re-)interpretation
}

Jaime de Souza Júnior (10 ${ }^{1 凶}$

This paper focuses on the centrality of media practices to discuss in a transdisciplinary way how the Covid-19 crisis has been framed and communicated in Brazil across different media spaces, whereas the country became the second in the world with most deaths due to the spread of the Covid-19 infection. This discussion mobilises Foucauldian genealogical and critical discursive perspectives (Foucault, [1970]1981, p. 73) to create intelligibility about how domains of media power-knowledge, such as professional journalism and social media, generate textual trajectories, discursive-semiotic and epistemic disputes through (re-)framings. Based on oligoptic decisions (Latour, 2005, p. 182; Souza Júnior, 2020, pp. 59-64), the article explores a multimodal corpus of transmedia texts. 11 posts have been selected for discussion, since they pave the way for tracing a set of interconnected and (in-)visible elements about the corona crisis. In turn, this paper seeks to: (i) give visibility and qualitatively discuss some of the perspectives that have circulated across media spaces along with their related repertoires of biopolitical and geopolitical (re-)interpretation and (ii) expose the dynamics of power and resistance that emerge through pandemic frames, and how the latter communicate a social event like the Covid-19 crisis.

\footnotetext{
${ }^{1}$ Federal University of Rio de Janeiro, Rio de Janeiro, Brazil. ${ }^{凶}$ email: souzajuniorprof@gmail.com
} 
Preliminary associations: the Covid-19 pandemic, journalism and two related presidential repertoires of communication

ince 2019, the far-right elected president, Jair Bolsonaro, has been ruling Brazil. On 11 March, 20201 , the World Health Organisation (WHO) labelled the coronavirus (SARS-Cov-2) outbreak a "pandemic". The first local case of the coronavirus disease (Covid-19) was confirmed on 26 February, $2020^{2}$. Since then, controversial geopolitical components have been marking the trajectory of Bolsonaro's governmental decisions in response to the pandemic. For the purposes of this paper, I shall focus on two of those components. Firstly, the enormous subnotification $^{3}$ of cases. Secondly, the temporary lack of digital transparency ${ }^{4}$ about the disease's official data, which has emerged with the militarisation of the Ministry of Health ${ }^{5}$.

It is important to take such components into account because they point to a relation that connects Bolsonaro's government and the pandemic to the domain of the media. If critically examined, the decisions and responses referred to suggest that governing through (or selecting) what can or cannot become visible about the corona crisis seems to have become central to the Bolsonarian exercise of power.

That exercise gives visibility to a 'novel' Brazil. It is mostly influenced by Donald Trump's administration and claims to be proud of being 'a free land' or a member of the so-called group of 'neoliberal', 'patriotic' and 'conservative' Western 'democracies'. In such a panorama, selectivity seems to orient this governmental suppression of information and their media practices, which promote the circulation of more convenient (geo-)political information. These traces of orientation (i.e. suppression or selectivity) throw light on a configuration that leads the Brazilian Executive Power to interfere with and, in some way, control when and how the communicational practices of institutions like the Media (or the Press) take place in this 'democracy'.

Despite all these grave inter-institutional problems, especially as they have emerged amid the Covid-19 crisis, various Brazilian news organisations have come together to create a consortium of journalists ${ }^{6}$, in order to reclaim their Constitutional and institutional journalistic role of informing the translocal population. On 19 June, 2020, the consortium reported that Brazil had, unfortunately, become the second ${ }^{7}$ country to surpass 1 million Covid19 cases. When this scenario became visible, over 50,000 people had already passed away, after contracting the coronavirus. Echoing Donald Trump's repertoire of interpretation in many respects, Bolsonaro's own way of communicating governmental and $\left(\right.$ geo- $\left.{ }^{8}\right)$ political responses to the corona crisis takes the media domain as a central dimension. Based on Foucault ([1970] 1981), I conceive that domain as a dimension of power-knowledge. This centrality emerges because, more than ever, these related presidential repertoires and the media practices that they generate are capable of (des-/re-) organising networks which can act in a transdimensional way (i.e. by reverberating the promotion of transit between on-line and offline dimensions).

\section{Theoretical constructs}

Henceforth, I seek to highlight the importance of theoretically considering different media spaces, the centrality of media practices and media discourse in order to: (i) transdisciplinarily understand the communication of both Covid-19 and the pandemic as a selective and productive framing process (Goffman, [1974]1975; Butler, 2010; Souza Júnior, 2021) and (ii) make visible repertoires of (re-)interpretation and some of the geopolitical and biopolitical effects that communication (in the referred sense) produces.
Framing the pandemic across media spaces: what may be involved or become (in-)visible in this process? Transdimensional networks and their socio-technical character (Latour, 2005, p. 80) bring into relationship the population's bodies, social or media spaces, technological devices, media screens, algorithms, (ro)bots, the field of journalism and internet users along with their semiotic work (Kress, 2015). Such a work creates an emergent configuration, and the latter can be described as a domain where media practices generate frames (materialised as digital texts), meanings and discourses that may be (re-)forged, circulated and (re-)interpreted. This description is an attempt to summarise what elsewhere I have proposed to call the transmedia order of discourse, where transmedia practices circulate or the process of transmediatisation becomes visible.

Henry Jenkins (2006, pp. 95-96) conceptualised transmediatisation by arguing that it would generate media practices that communicate through different media spaces and construct messages of "convergence" or, as I understand it, a sense of cooperation and stability in this process of circulation. In my transdisciplinary theorisation (Souza Júnior, 2020, pp. 143-154), through which I have sought to update the Foucauldian concept of order of discourse (Foucault, [1970]1981) relating it to the domain of media discourse, I highlight the emergence of (multi-) semiotic transgressions (Pennycook, 2007; Souza Júnior, 2020, p. 17) and struggles involving the (re-)interpretation of messages, discursive fields, practices, performances along with meanings that circulate across different media spaces.

Transmediatisation, therefore, may produce (re-)framings and on-line textual disputes that can (de-)stabilise the communication of transdimensional events (e.g. contemporary situations of conflict and/or crisis). In such struggles, domains of powerknowledge (e.g. 'authorised'/disciplinary medical, juridical and journalistic discourses or 'non-authorised'/social media users' collaborative semiotic work) can be (re-)articulated as a mix of power-knowledge dimensions. The intertwining of those dimensions contributes to constituting multilayered (or hybrid) discourses, such as the Covid-19 discourse of crisis ${ }^{9}$.

The constitutive fields of this hybrid discourse and the power operations that derive from those combined fields (whilst the pandemic is communicated) can make visible different (re) actions and effects. These (re)actions and effects become exposed via the media domain along with its own discursive potentials for distributing and rearticulating information every time that we (as participants in a network of media screens) experience situations of conflict and/or crisis. Since it contributes to (re-)articulating dimensions of power-knowledge and the hybrid discourses that circulate through digital(-ised) texts, the transmedia order of discourse gives rise to practices of transmediatisation, which become visible through the collaborative semiotic work of internet users. Thus, through that order, power operations and resistance emerge from multiple framing spaces. Internet users' transmedia practices may 'compete' with those of 'authorised' or professional journalism, making the latter discursive field vulnerable to social media users' communicational interferences and these may trigger epistemic disputes.

In such disputes, those interferences can, on one hand, delegitimise (e.g. by denying, invisibilising or defying) distinct domains of expert power-knowledge (including that of journalism) or, on the other, make visible and reinforce the status of legitimised 'authority' of these domains in relation to what is circulated about the pandemic. More precisely, in the Brazilian panorama of the Covid-19 crisis, Bolsonaro's media practices and his performance as a social media user point to two relevant and interconnected aspects. Firstly, such performances and practices put the spotlight on a presidential transdimensional ethos that can be seen as a 'non-authorised' but recalcitrant commentator. 
Secondly, Bolsonaro's performances produce repertoires of interpretation that can be incorporated, replicated or reinterpreted and countered in the circulation of transmedia practices along with the complex process that such practices generate.

Textual trajectories and on-line disputes: communication, government, and multimodal (dis-/re-) orientation about the pandemic across media screens. Digital circulation generates a complex multimodal process, which communicates through verbo-visual frames and messages. Such a process allows Bolsonaro to exert power through different notions of 'government'. Here, I am drawing on the Foucauldian notions of governmentality and pastoral power ${ }^{10}$ (Foucault, 1982, pp. 783-784) to describe a particular way of operationalising power that produces "technologies of conduct" in association with a network of media screens. To some extent, this configuration of the exercise of power leads the Brazilian president to respond to the pandemic by mobilising repertoires of interpretation and a network of media screens. Through the latter, that repertoire can be sustained by his social media supporters: the Bolsonarian coframers. These co-operative participants, as a network of coframers, can expand the reach of their president's beliefs and disseminate them.

In this way, we can see that the notion of government and the dynamics it produces can be operated through the media domain, by forging and distributing social media repertoires of interpretation and conducts, as if they were individual (i.e. from a social media 'friend') and not presidential. This blurry configuration can contribute to making such conducts not only visible, but also embraceable by individual subjects who emerge as Bolsonarian co-framers. Across other media screens, such conducts can be replicated as a potential totalising presidential/ state (infra-)norm (or an almost 'invisible' norm). The conducts and norm referred to can, then, (dis-)orient bodies and part of the population governed by Bolsonaro in the context of the pandemic. Moreover, the presidential communicational 'style' and the governmental network of expansion it produces across different media or translocal spaces along with the transdimensional participation of his supporters may (de-)stabilise 'authoritative' practices of communication. With the help of attention, which emerges as a 'productive commodity', dynamics of (de-) stabilisation produce (re-)framings. As an effect, such dynamics can impact the population's visual field. They may (re-)forge what/who captures people's attention and, then, what individuals see in relation to the medical dimension of the pandemic or other interrelated issues (e.g. a country's economy, health/educational systems or un/employment).

The potential for expansion alluded to, however, implies visibility; and, hence, more contact and co-existence across media spaces with other transdimensional participants who are part of the translocal population, but in no way supporters of Bolsonaro's beliefs or responses regarding the Covid-19 crisis. Here, two aspects need to be considered. Firstly, as the Bolsonarian network searches for visibility, they may reaffirm their president's opinions, beliefs or responses as legitimised. Secondly, the abovementioned contact (associated with frictions between transmedia practices and repertoires of reinterpretation) may pave the way to expose Bolsonaro's communicational and biopolitical strategies of government.

Based on Foucault ([1975-1976] 2003, p. 245) and Venn (2009, pp. 208-209), it is possible to reinterpret biopolitics as a technology of power (or a rationality) in the panorama that I discuss. This technology may generate a process that allows for the selective politicisation and/or militarisation of the biomedical discourse. In that process, such a technology or rationality can affect/influence how certain dimensions of the social world (e.g. government, economy and, in a controversial way, religion) are biopolitically operated or mobilised through a network of media screens. Drawing on Butler (2010, p. 1), it is also possible to say that the operation of that rationality has a biopolitical impact on bodies-more precisely, on how people selectively (re-)frame or (re-)interpret deaths and what/who should(not) count as a grievable 'life'/loss. As biopolitics is operated and 'communicated' through such schisms that point to what counts or should be excluded, government and (bio-) power may be exerted through the socio-technical capillarity offered by the media domain and the transmedia order of discourse. Then, the operation of that biopolitical rationality, its related repertoire of interpretation and (re-)framing dynamics can be expanded, making visible different biopolitical effects that we will see throughout the discussion section.

As I have already suggested, when the co-existence of networks of media screens is perceived, implications may be derived from this configuration that becomes visible across media spaces. That co-existence can catalyse frictions that involve Bolsonaro's governmental strategies of communication during the pandemic. The digital events (Souza Júnior, 2015, p. 318) that have circulated with the following hashtagged memetic expressions, \#StopBolsonaro and \#GoBolsonaro, can contribute to illustrating this point. An example of such implications: frictions give rise to textual disputes that attract more expert re-framers. They orient and coconstruct a related network of social media supporters along with their collective-collaborative transmedia practices of reinterpretation. Those practices may be rearticulated and circulate, informed by expert discourses' authority, which can be (re-) forged through the media domain. When the semiotic work of reframers from professional journalism and social media users emerges, the media domain becomes a central dimension of power-knowledge-it turns into a discursive arena in the context of the corona crisis.

Keeping in mind the Brazilian scenario, I resort to Foucauldian genealogical and critical discursive perspectives (Foucault, [1970] 1981, p. 73) to create intelligibility about how domains of media power-knowledge, such as professional journalism and social media, generate textual trajectories that point to discursivesemiotic and epistemic disputes. Such disputes bring to the fore networks that involve Bolsonaro, his social media supporters as co-framers, and those who oppose or contest the Bolsonarian network as re-framers. In this direction, I will not only focus on the chronological trajectory of the pandemic as a transdimensional social event, but also on the discursive modulations that become visible in the domain of government and in that of the media. The interconnexion between such domains points to transmedia practices, journalism, social media users, processes of (re-) interpretation and their reverberations in relation to the aforementioned death toll.

\section{Corpus and methodological approach}

The corpus comprises commentaries from the field of journalism and social media users' tweets. I frame such texts as replies to what circulated videos, news items (or their headlines and photographs) presented at that time. The news items and videos (from state and traditional media websites/channels) have been selected by Marlos Apyus, who presents himself as a professional journalist and used to work for a local traditional media website. He intended to reconstruct through his commentaries the local trajectory of cases, deaths and Bolsonaro's (re)actions in the local media. That reconstruction has been disseminated as a Twitter thread $^{11}$, which (until 26 June, 2020) had 4500 retweets and 11,000 likes. On Twitter, a thread allows profile holders to 
compile an assemblage of digital(-ised) texts, which may communicate their chronology or develop other unpredictable purposes and meanings, depending on the (re)actions that the thread produces, as it circulates. This compilation of multimodal posts has gained visibility and productively attracted the attention of 'non-authorised' Twitter users as (re-/co-) framers along with their replies/comments.

To capture the discursive modulations mentioned in 2.1, I implement oligoptic procedures (Latour, 2005, p. 182; Souza Júnior, 2020, pp. 59-64), in order to: (i) explore that thread; (ii) select a set of posts presenting relevant interconnexions that multimodally and/or discursively project a 'conversation' (about what such posts convey) and contribute to expanding the complexity and/or the reach of the thread; and (iii) discuss the posts qualitatively, seeking to understand when and how geopolitical or biopolitical repertoires of (re-)interpretation seem to (dis-/re-) orient framers who engage in on-line textual disputes in this context of crisis. Oligoptic procedures also lead me to describe (and focus on) what emerges through the 'voice' of the actors that are involved in the dynamics projected by the thread. Latour (2005, p. 12) reminds us that the researcher should not risk silencing the voice of the actors involved in the events under discussion. Based on the author (2005), I contend that neglecting this, would, on one hand, contribute to developing the discussion in an unbalanced way, amplifying the certainties of the researcher, whose theoretical and methodological (re-)framings are never neutral. On the other, this unbalanced atmosphere would collaborate to not properly giving visibility to the voice of the actors. To this end, I pursue that balance, so that I can point to relevant forms of connectivity by paying close attention to what the actors involved in the event project.

Taking this into account, I have explored the thread and selected 11 public posts (written in Brazilian Portuguese) that circulated between 22 June and 24 June, 2020. In turn, this dataset has been considered relevant because it allows me to focus on the discussion of the following biopolitical and geopolitical interconnected elements that may become (in-) visible across media spaces and 'take on' different meanings during the pandemic. These are: (i) the Covid-19 virus; (ii) bodies, social spaces and strategies of prevention; and (iii) deaths, government, rationality and the population in Brazil. The sense of trajectory that is implied in the genealogical conception also allows me to articulate the oligoptic approach (and its methodological procedures) to explore, indeed, a reduced number of posts, but in particular those that have been framed as qualitatively relevant. So, as I describe the posts in detail, I seek to generate intelligibility about the corona crisis in the panorama that I capture. At this point, it is important to stress that the proposal of generating intelligibility outlined earlier should not be equated to an attempt to provide all the fundamental 'explanations', as if this research were capable of providing 'answers' to all the aspects and dynamics that are involved in the transmediatisation of the Covid crisis as a process. Since it is impossible to capture or provide exhaustive 'explanations' that would (beforehand) define what that process is, my proposal simply seeks to make visible elements that can contribute to understanding particular interconnected aspects of the pandemic that emerge in the Brazilian panorama.

My engagement in the exercise of detailed description is consistent with the transdisciplinary recommendations from the social sciences, which equate that kind of exercise to "laboratory" work, as it is conceived in the so-called hard sciences (Latour, 2005 , p. 124). The interconnexion between my choices of theoretical constructs and methodological approach leads me to sustain the consistency of the rearticulations that I propose. They allow me to project and expose what has been made (in-)visible through media spaces, by considering not only textual trajectories

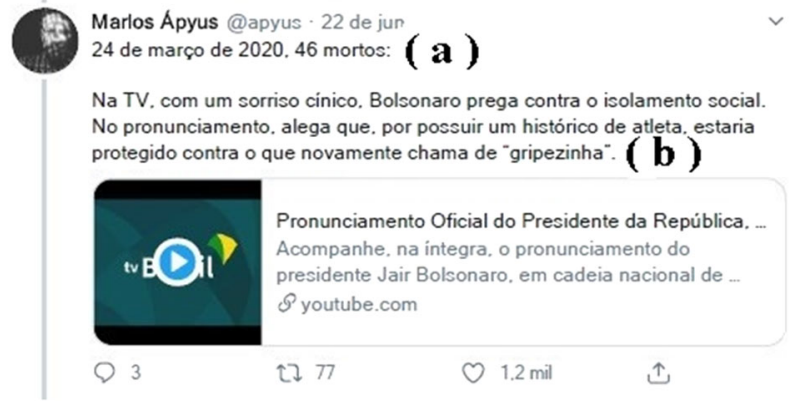

Fig. 1 On Twitter, a journalist's commentary points to how Bolsonaro has been framing the virus. Translation (a) 24 March, 2020: 46 deaths.

Translation (b) On TV, with a cynical smile, Bolsonaro preaches against social distancing. In his pronouncement, he claims that, for having a background as an athlete, he would be protected against what he, again, calls "a little flu".

but also discursive-semiotic and epistemic disputes, whose traces of (re-)signification are projected by the actors as they take part in the event under discussion.

\section{Discussion}

Throughout this section, I intend to address some of the perspectives and interconnexions projected by the thread entitled "How Jair Bolsonaro tried to sabotage anti-Covid efforts" ${ }^{12 "}$. My discussion will be divided into three stages.

Frames, textual disputes related to the Covid-19 virus and their effects. By pointing to the different ways that the virus has been framed across media spaces, a pathway is opened to critically explore: i) the meanings that emerge through the Bolsonarian network, as these participants co-operate and promote their repertoire of interpretation regarding the coronavirus; and ii) the interconnexions which become visible through productive reframings, repertoires of reinterpretation and meaning disputes in the Brazilian panorama of the Covid-19 crisis. Figure 1 introduces this discussion.

In Fig. 1, it firstly becomes important to observe the complexity of the process of transmediatisation, as it shows (multi-)semiotic work crossing different media spaces and (re-) framing dynamics that point to on-line textual disputes. In this regard, we can see a hyperlink from TV Brasil (i.e. Brazil's state TV channel) and a video being transmediatised, when it is redirected to a journalistic Twitter profile. The content of the video refers to one of Bolsonaro's official pronouncements, and, as reported by the journalist, the Brazilian president "again" frames Covid-19 as a "little flu". When the disease and its related virus are framed in this recalcitrant way, Bolsonaro contributes to activating a biopolitical repertoire of interpretation through digital circulation. That repertoire forges a belief that can be shared and is capable of orienting the Bolsonarian network of coframers through digital repetition and techno-preacherism (cf. "Textual trajectories and on-line disputes: communication, government, and multimodal (dis-/re-) orientation about the pandemic across media screens"). From a critical discursive standpoint, it is possible to say that when Bolsonaro promotes that understanding of the disease as a "flu", the virus takes on a new inter-related meaning and an interconnected process of hierarchisation emerges. As that process is developed, two effects may become visible.

The first (and more explicit) effect would be the minimisation or naturalisation of the disease. Bolsonaro contributes to making visible a biopolitical dispute. That dispute points to how he 


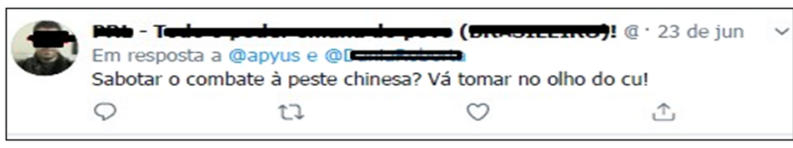

Fig. 2 A Bolsonarian co-framer talks about the Covid-19 virus.

Translation: Sabotage the efforts against the Chinese plague? Go fuck yourself!

selectively frames Covid-19 and, then, to how it can be communicated as 'less dangerous' or 'less deadly'. This communicational scenario, therefore, would point to the discursive implication of defying the medical discourse-what Bolsonaro has done as a recalcitrant and non-specialised commentator (cf. "Framing the pandemic across media spaces: what may be involved or become (in-)visible in this process?"). The repetition of that kind of performance may allow for conducts of delegitimisation. The productivity of such conducts collaborates to generate (mis-)interpretations, suggesting that the virus would only cause "a little flu". This suggestion contributes to forging a belief that facilitates the controversial consolidation of 'anti-social practices as social practices'. The association of such a belief with those practices may lead to the abandonment of precautions like "social distancing", as shown in Fig. 1B.

The second (and less explicit) effect would be the forging of a biopolitical scenario that legitimises a kind of Bolsonarian 'prototypical body' in Fig. 1B. The self-described "athlete's" body seems to have been conceived as a 'superior' biopolitical entity. The latter can lead one to interpret the virus as 'inferior'insufficient, like the "little flu" that it would cause. Then, a biopolitical repertoire of interpretation and government is forged not only by promoting a belief that disregards the lethal potential of the virus, but also by offering to the local population a specific kind of body. It emerges here as an important instrument of communication or a biopolitical 'message'. The latter can affect how locals make sense of: (i) their lives; (ii) anti-Covid efforts; and (iii) Covid-related deaths during the pandemic.

Such a corporeal model (or 'anti-Covid-19 costume') may be seen as the ideal instrument of government that a large part of the population can eventually 'put on', whilst people ignore social distancing. Thus, that instrument would be capable of sustaining collective performances that are bodily communicated, whereas bodies, 'empowered' by the purported protection of such a 'costume', may reproduce (in a pastoral fashion) conducts of delegitimisation. Those conducts can be replicated (like in rituals or cults ${ }^{13}$ ) across the whole population, without, nevertheless, openly communicating a silent dimension (or infra-norm) of hierarchisation that produces a particular social division. These notions of hierarchy and division emerge because in that process of replication not all local bodies are provided with the same 'hierarchising armour' (or 'costume'). Here, the armour/costume can be translated as guarantees of protection, like medical treatment and hospitalisation, which would allow the population to see the virus as 'inferior' in the same way that the Brazilian president suggested. In the 'neoliberal' Brazil of these days, those presidential guarantees (provided by taxpayers) are not equally available for many who (have to) embrace such a biopolitical conduct. Section "(Re-)framing deaths, government and the population in Brazil during the pandemic" readdresses this issue (see also endnote starting with "This issue points to the importance of taking...”).

So far, we have seen that the biopolitical delegitimisation of Covid-19 and its virus generated a relevant instrument that seems to help Bolsonaro to exert power during the pandemic. In addition to that, a geopolitical repertoire of interpretation and the way that it has been conceived, co-operated and distributed contributes to sustaining his governmental practices. In the next figure (Fig. 2), we can see more clearly how that dimension can be co-operated.

As noted in section "Framing the pandemic across media spaces: what may be involved or become (in-)visible in this process?", collective semiotic work may (re-)articulate dimensions of power-knowledge, modulating what is communicated in contexts marked by discursive hybridity, like the Covid-19 crisis. A discursive modulation becomes visible when the co-framer in Fig. 2 indirectly contests the medical-scientific orientation which the journalistic Twitter profile mobilised to frame the virus. Then, as I understand it, this co-framer replies to the designer of the thread and seems to defy both the journalistic and the medicalscientific authority associated to the field of expert discourses. Whilst the Bolsonarian participant in Fig. 2 frames the virus, that interpretation projects its interconnexions with one of the most productive dimensions of power-knowledge during the pandemic: the dimension of conspiracy theories (CTs, henceforth) (Sunstein; Vermeule, 2009).

Commonly associated with non-hegemonic groups, Covid-19 CTs emerge as governmental strategies of soft power ${ }^{14}$, which, in the geopolitical panorama under discussion, can be characterised by the way that, discursively, such strategies influence not only individuals, but also other countries' administrations through a repertoire of media practices and transdimensional performances. As it stands, I address a less usual epistemic conception of 'soft power' here. I link it to the domain of CTs in order to reinterpret them, based on Foucauldian notions of power and knowledge. In this way, I consider that knowledge may emerge from multiple sources and its 'authority' can be forged in different ways. Hence, it would not be confined to 'authorised'/disciplinary fields. Their 'authority' or 'epistemic integrity' may be more often challenged, if the transmedia order of discourse is considered.

For this, I am suggesting a genealogical reinterpretation of the CT which is about to be discussed. I conceive this CT as an element of power-knowledge that can productively "organise its disorders" (Foucault, [1970]1981, p. 66). So, this trace of productivity leads me to frame CTs, nowadays, as "monsters on the prowl whose form changes with the history of knowledge" (Foucault, [1970]1981, p. 60). Being part of the repertoire of practices mobilised by the presidents of the United States and Brazil to, respectively, suggest that China has manufactured ${ }^{15}$ the Covid-19 virus and claim that the Asian country "should be held accountable" for the current pandemic, CTs have been generating 'semiotic bombs' and/or multimodal texts that circulate through different media and translocal spaces.

The memetic expression "Chinese plague" ${ }^{16 ", ~ i n ~ F i g . ~ 2, ~}$ exemplifies how such bombs materialise through selective frames. Discursively, they point to the replication, incorporation and cooperation of a geopolitical repertoire of interpretation that approximates Bolsonarian and Trumpist networks of co-frames. In this way, as CTs circulate, the Covid-19 virus is not exclusively seen through the medical-scientific lenses like an element that demands anti-Covid efforts. Instead, the virus seems to be taken as an 'ally' that can be associated with CTs. The CTs about the virus can capture our attention and the latter emerges as a productive commodity (cf. "Textual trajectories and on-line disputes: communication, government, and multimodal (dis-/re-) orientation about the pandemic across media screens"), which contributes to producing and activating a dimension of powerknowledge. That dimension becomes visible through the circulation of CTs (as an emergent instrument of soft power that helps to blame or facilitates punishment). Hence, when CTs about the "Chinese virus/plague" circulate, the term "Chinese" does not simply 'represent', based on a 'notion of origin' that would only indicate in a 'transparent' or 'neutral' way the country that has 


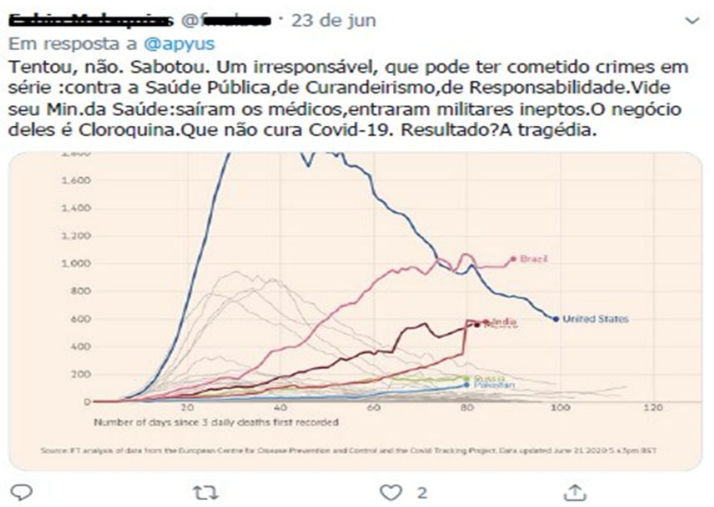

Fig. 3 A Twitter user's multimodal performance and how, as a re-framer, that user views the Covid-19 virus. Translation: Tried, no. [He has] sabotaged. An irresponsible [president], who might have committed a succession of crimes: against Public Health, charlatanism, [and a presidential crime of] responsibility. See his Ministry of Health: the medical doctors left, and the inept military men stepped in. Hydroxychlroroquine is their business. That does not cure Covid-19. Aftermath? The tragedy.

first reported the existence of the coronavirus. When "plague" is chosen to replace the medical terminology 'virus', the former resonates the neo-pentecostal influence over the Bolsonarian exercise of power (cf. "Textual trajectories and on-line disputes: communication, government, and multimodal (dis-/re-) orientation about the pandemic across media screens"). It is that influence, which, discursively, can collaborate to forge the delegitimisation of the virus as a bioscientific entity.

Through this discursive 'breach', CTs may emerge more easily associating the use of "plague" with religious/biblical ${ }^{17}$ discursive dimensions that complexify the Covid-19 discourse of crisis. Complexification contributes to recycling and geopolitically ${ }^{18}$ projecting the dichotomy of East versus the so-called Western democracies (cf. "Textual trajectories and on-line disputes: communication, government, and multimodal (dis-/re-) orientation about the pandemic across media screens"). In turn, this scenario provides a memetic tool of soft power for Donald Trump to frame China and successfully influence Bolsonaro's administration as well as part of the local population to interpret that country in at least two ways: (i) geopolitically and (ii) biopolitically. The development of this collective framing strategy incentivises participants to engage in the translocal and transdimensional disqualification of Chinese products and/or technology (e.g. 5G). Discursively, that strategy may also 'authorise' the stigmatisation (or the eventual dehumanisation) of Chinese bodies.

As noticed until now, the Covid-19 virus has not been framed exclusively by the lenses of medical-scientific and journalistic discourses. That panorama has shown a dispute regarding the way that a co-framer perceived the virus. Figure 3 indicates that more disputes have emerged, when re-framers entered the discursive arena of the thread.

As we can see in Fig. $3^{19}$, re-framers enter the transmedia arena and seem to direct their reframing focus towards selective invisibilisation and/or discursive dislocations. In this way, a repertoire of reinterpretation is co-constructed or expanded, and not necessarily sustained/preserved (as an effect of governmentality) like co-framers would do. In this regard, it is important to observe how discursive hybridity interconnects the journalistic, juridical and medical-scientific discursive domains here. They project interconnexions that allow for co-constructions (e.g. "Tried, no. [He has] sabotaged"). In Fig. 3, we can also perceive discursive expansions that point to biopolitical implications (e.g.

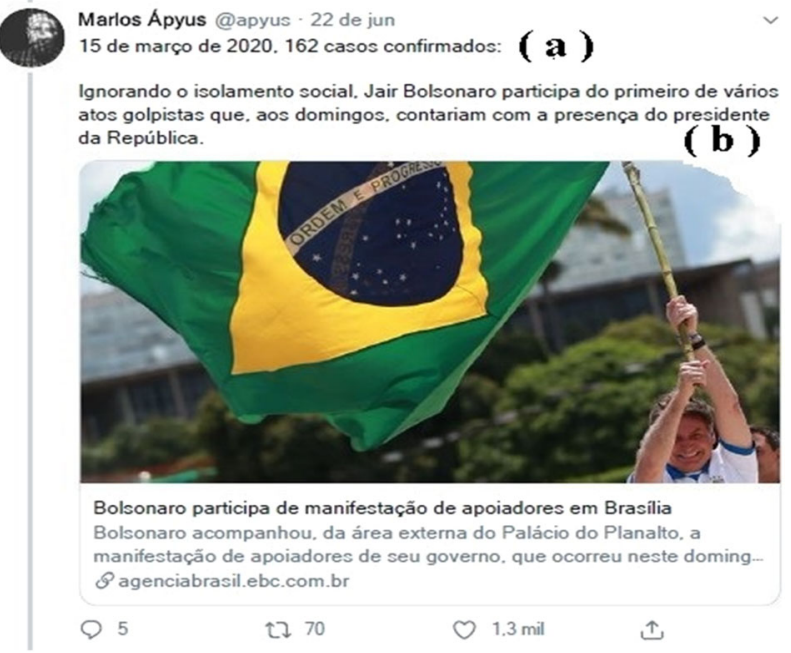

Fig. 4 On Twitter, a journalist's commentary on Bolsonaro's conduct, his supporters and social distancing. Translation (a): 15 March, 2020: 162 confirmed cases. Translation (b): Ignoring social distancing, Jair Bolsonaro takes part in the first of many self-coup-motivated street demonstrations in which, on Sundays, the president of the Republic would be present.

"[...] a succession of crimes: against Public Health, charlatanism, [and a presidential crime ${ }^{20}$ of] responsibility").

In relation to how the coronavirus has been re-framed, after being viewed as "the Chinese plague", it becomes visible that the participant in Fig. 3 redirects the virus to the medical-scientific discursive field. That field contributes to activating a repertoire of reinterpretation that relates the virus to the disease it causes (i.e. "Covid-19"). This activation and its related reorientation emerge with help of multimodal and discursive contributions. The graph, exposing scientific data and the rise of death curves, is one of the semiotic resources produced by the domain of expert discourses that, through digital repetition and circulation, 'co-authorises' the re-framer in Fig. 3 to resist the discursive-semiotic minimisation and/or instrumentalisation of the virus.

This framing of resistance and a sense of discursive 'coauthorisation' become visible when a medical-scientific 'verdict' or 'diagnosis' is projected, reassuring the deadliness of the disease (i.e. "[...] the inept military men stepped in. Hydroxychlroroquine is their business. That doesn't cure Covid-19"). Here, the reframer disputes two elements: (i) a purported medical-scientific 'truth'; and (ii) a particular kind of medical-scientific 'authority' that can be viewed as self-proclaimed or self-performative. That 'authority' has been discursively shared as a belief by the Trumpist and Bolsonarian networks along with the communicational performances of a particular segment of the Brazilian military-more precisely by those (in active duty or reserve officers) who have become members of Bolsonaro's administration. Their belief suggests that Chloroquine would be effective against the Covid-19 infection-what has been dismissed ${ }^{21}$ by researchers.

Framing disputes involving bodies, social spaces and strategies of prevention. In this section, I will critically discuss: (i) the role of 'bodies as messages' that may be (re-)framed and communicated and (ii) how such 'messages' project multimodal interconnexions that contribute to influencing the (re-)interpretation of social spaces and strategies of prevention (or antiCovid efforts) in the local panorama. Figure 4 will lead us to look at how communication and that process of (re-)interpretation may unfold. 


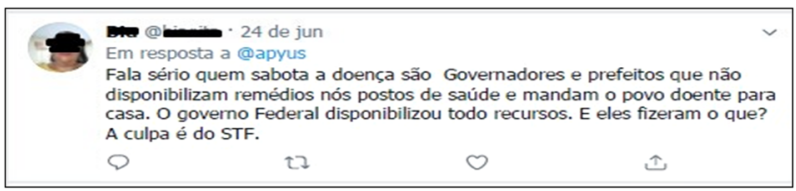

Fig. 5 A Bolsonararian co-framer sustains the position that Bolsonaro's actions are not acts of sabotage. Translation: Get real! [Those] who sabotage [sic] the disease are the governors and mayors, who have not supplied medicine to the medical facilities and send ill people back home. The Federal government made all the resources available. And what have they done? It's the Federal Supreme Court's fault.

In Fig. 4, the journalistic profile transmediatises a news item from the website of the Brazilian state TV to Twitter. This transmedia performance invites us to look at how a biopolitical repertoire of reinterpretation emerges multimodally, when the following interconnected elements are re-framed: (i) the pandemic; (ii) streets; (iii) the demonstration and its reported "selfcoup" orientation; and (iv) the participants. In a hybrid way, that repertoire intersects the medical-scientific expert discourse with the journalistic dimension to make visible how the Brazilian president has been "ignoring social distancing" along with his supporters during the pandemic. "Ignoring social distancing", in that context, develops a complex configuration in which the presence of bodies in the streets sends a multimodal message that biopolitically defies the 'authority' of death over life via the domain of media discourse. That 'authority' (or the 'authorisation' indicating that it is 'safe' to occupy the streets during the pandemic) would be normally operated through the frames of the medical-scientific domain. A potential infra-norm seems to be collectively communicated every time that Bolsonaro manages to make his supporters 'welcome' gatherings during the pandemic.

Here, I keep in mind: (i) interconnexions that point to the way the Bolsonarian network interprets the virus: (ii) their belief in an anti-Covid costume/armour (which they would share with their president-cf. "Frames, textual disputes related to the Covid-19 virus and their effects"); and (iii) the gatherings and the flag. Such items and their projected interconnexion lead me to frame those as elements that would collaborate to constitute such subjects as 'Brazilians' or 'patriots'. They would be seen as 'special' or 'superior' citizens, if the Bolsonarian perspective is taken into account. In this sense, an infra-norm seems to be communicated amongst those participants. It may turn anti-Covid efforts into 'obstacles' that need to be eliminated, paving the way to complexify the Covid-19 crisis with the emergence of street demonstrations. This complexification collaborates to make visible what the journalistic profile re-frames as "self-coupmotivated" performances. Hence, seeing social distancing as an 'obstacle' (and distributing this conception in a transdimensional way) can produce a hybrid discursive configuration, as the crisis unfolds.

That configuration contributes to the emergence of performances that may defy not only the 'authority' of the medicalscientific discourse, but also the authority of the Brazilian State itself, which is equally constituted by the Executive, Legislative and Judicial Powers. This three-branch configuration has been designed throughout the Brazilian Constitution to prevent scenarios that could threaten democracy, where, for example, the authority of the State would be taken as one that could be exerted exclusively by the President of Republic. Here, the complexification of the crisis makes visible the dimensions of conflict. Those dimensions involve the authority of each Constitutional Power, as well as the way that the Bolsonarian network and re-framers perceive how such Powers operate (i.e. their Constitutional prerogatives and limitations) during the

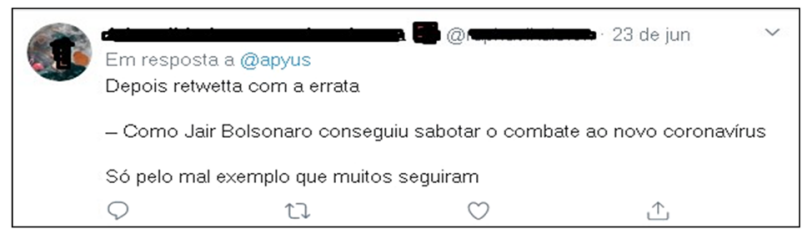

Fig. 6 A re-framer conceiving Bolsonaro's performances as sabotage actions. Translation: Later, retweet [the thread's title], issuing an erratum - how Jair Bolsonaro has managed to sabotage anti-Covid efforts Simply because of [Bolsonaro's] bad examples that many have followed.

pandemic. Some of the perspectives that contribute to exposing a 'dialogue' between crisis and conflict will be discussed through Figs. 5 and 6 .

In Fig. 5, the Bolsonarian co-framer disputes the title of the journalistic thread (i.e. "How Jair Bolsonaro tried to sabotage anti-Covid efforts"), arguing that the federal administration took the necessary measures to prevent Covid-19-related complications/deaths (i.e. the transfer of medicine ${ }^{22}$ and resources) that would allow local state and municipal administrations (i.e. "mayors and governors") to deal with the spread of the disease. In this way, that co-framer seems to sustain a claim that the biopolitical implications that emerge from this scenario have nothing to do with the Federal Executive Power. Here, those implications point to how such bodies and lives would have been treated (i.e. "ill people" sent "back home").

Additionally, it should be noted that whilst this conflictoriented perspective proposes to put the spotlight on other local governmental leaders (i.e. "And what have they done?"), it also promotes what can be seen as a non-specialised interpretation of the juridical dimension that constitutes this hybrid panorama of crisis. In turn, that biopolitical repertoire of interpretation selectively exempts Bolsonaro's administration from its coordinating responsibilities in relation to the strategies of prevention at the municipal and state levels during the pandemic. His administration would not be exempted from such a responsibility, as ruled by the Federal Judiciary Power (i.e. "STF"/the Federal Supreme Court). Thus, the Bolsonarian coframer mentions the Court to blame it. That projects its Constitutional authority as being questioned-a framing performance that we have already seen in Fig. 4.

In Fig. 5, we have just seen that the co-framer disputed the title of the thread and the discursive authority of the field of journalism (i.e. "Get real!"). That would contribute to exempting Bolsonaro's administration from its responsibilities, whilst sustaining the view that other executive spheres along with the Judicial Power should be blamed for the complexities related to ill bodies and strategies of prevention. In spite of that, in Fig. 6, we can see that a re-framer reinterprets the same element of hedging (i.e. "tried to sabotage") that accompanies the thread's title, making visible a dispute which that particular element has triggered.

So, in Fig. 6, we see that, firstly, the re-framer expands and reinterprets not only the discursive dimension of journalism (i.e. "Later, retweet [the thread's title], issuing an erratum"). After that, this participant re-frames Bolsonaro's governmental performance in relation to the strategies of prevention (i.e. "How Jair Bolsonaro has managed to sabotage anti-Covid efforts"). The italicised modulation in the sentence, above, suggests a degree of assertion. However, the re-framer does not seem to defy the journalistic dimension of power-knowledge to disrupt the discursive authority of that specialised field. The participation of this re-framer seems to propose a re-framing dynamics based on collaborative semiotic work or epistemic collaboration. Here, that kind of work (or collaboration) is understood as an emergent 


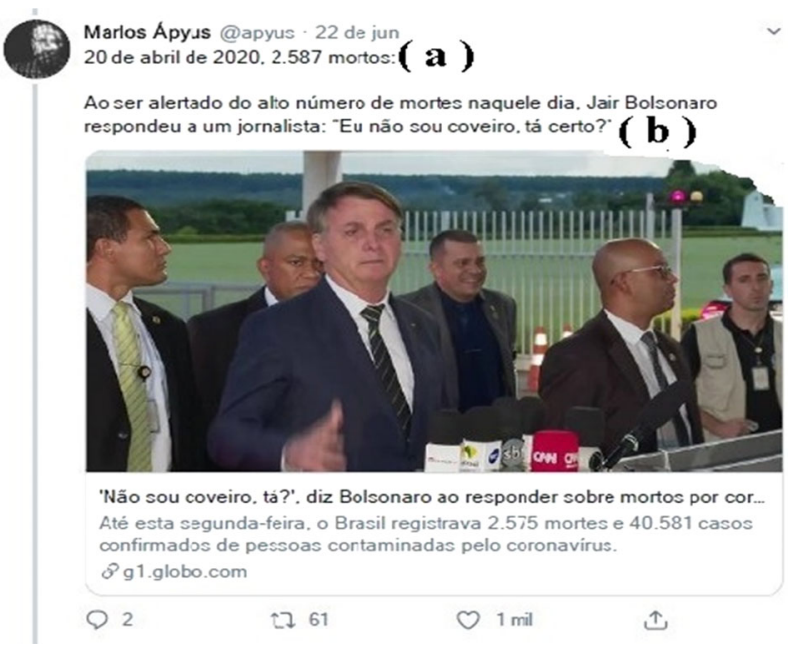

Fig. 7 Bolsonaro's reaction, after being informed about the Covid-related deaths of locals. Translation (a): 20 April, 2020: 2587 deaths. Translation (b): When told about the large number of deaths on that day, Jair Bolsonaro replied to a journalist: "I am not a grave-digger, okay?".

form of power-knowledge. It can renegotiate or co-construct the meaning of previous messages, by operating and making visible epistemic reorientations along with reinterpretations in hybrid discursive configurations like the Covid-19 crisis.

Through the mobilisation of that repertoire, the re-framer in Fig. 6 problematises what the co-framer in Fig. 5 has not made visible: the role of Bolsonaro's body (and of his presence) in the streets during the pandemic. From a discursive-semiotic perspective, the recalcitrant and multimodal circulation of corporeal images in such social spaces (and during the corona crisis) may generate productive frames that can communicate a biopolitical stance. The latter can be reinforced as "examples" through techno-preacherism and, then, capture the attention of other locals. When professional journalism denounces the occurrence of gatherings associated with Bolsonaro and his supporters, this framing strategy may trigger backlash; but it may also backfire, if those who are framed in pandemic denial are simply exposed without any indication that they (will be or have been) sanctioned (e.g. get a fine).

This scenario of exposure (whose expectation of 'resolution' in the form of social sanction may not always become materialised through a network of media screens) can contribute to (re-) forging perceptions based on denial. That dynamics of (re-) forging may intensify the socio-technical consolidation of a behaviour that needs to be biopolitically re-interpreted, so that one can prevent it from replicating through techno-preacherism, from media screen to media screen, from body to body. It is the 'architecture' of a socio-technical configuration that seems to lead the re-framer to re-interpret the governmental performance of Bolsonaro as a presidential "sabotage" against the strategies of prevention (i.e. "Simply because of [Bolsonaro's] bad examples that many have followed"). Once this architecture becomes visible, the notion of government under discussion points to the biopolitical relation that emerges through frames and sociotechnically interconnects bodies, media screens, social spaces and a scenario of (dis-)orientation and (dis-)legitimisation of antiCovid efforts. Such efforts may be perceived either as an obstacle or as an ally during the pandemic.

Given the complexity of such a context, it is no surprise that deaths emerge as an additional biopolitical effect. They tend to mark the pandemic trajectory of countries where the scenario just described prevails. As it stands, it is necessary to discuss, in the next section, how deaths, government, rationality and the population in Brazil become (dis-)connected elements.

(Re-)framing deaths, government and the population in Brazil during the pandemic. In this section, it becomes crucial to look at how the Covid-19 crisis has developed further in Brazil. At this point, the pandemic is associated with a growing number of deaths/losses. This concerns how the dimensions of government and power are being operated. Figures 7-9 will lead me to discuss how pandemic frames point to discursive modulations and disputes revolving around the biopolitical (re-)interpretation of bodies, deaths and the Brazilian government across media spaces.

In Fig. 7, we can see that a news item from a traditional media website is shared, and the Twitter journalistic profile, by quoting part of the news item's headline, reports what Bolsonaro answered when he was informed by local journalists about the growing number of Covid-related deaths: "I am not a gravedigger, okay?” Here, Bolsonaro's reply makes visible a discursive modulation and a biopolitical repertoire of interpretation. The latter collides not only with the expectation of the local journalists who were at the reported event on that day, but also with their repertoire of reinterpretation, which projected a more inclusive framing orientation. That orientation suggests that, for the journalists, the reported losses mattered, and Bolsonaro ought to have said something ethically compatible with that situation/ritual.

For this, a sense of 'presidential deviation' in relation to such an expectation becomes visible. That notion of deviation points to interconnexions which have to do with the following items: government, the population, deaths and governmental responsibility. In this way, the governmental repertoire of interpretation that Bolsonaro mobilises and (most importantly) the modulation that emerges from his framing performance still 'say' a lot about how the Bolsonarian network may selectively separate responsibility from the notion of government. This discursive separation collaborates to disseminate specific pandemic frames that, biopolitically, dispute and problematise the political meaning of Covid-related deaths during the corona crisis.

The first aspect which becomes visible in this 'clash' of conceptions is that in this configuration of government the reported fatalities and the notion of death seem to be biopolitically interpreted simply as 'numbers', or conceived from a 'mathematical' viewpoint. Bolsonaro's reply, then, projects the dehumanisation of such losses, whilst he: (i) claims to be a conservative 'pro-family' president, but, nevertheless, did not seem to recognise in those losses the face of humanity or the potential family bonds that those dead people might have lost; and (ii) promotes himself as a 'patriot', but, nonetheless, has not expressed any kind of affect, which could have been evoked in line with his own political views, for example, through a sense of compatriotism for those who had passed away to 'unite' the nation(-state).

Hence, this projected understanding of the reported deaths as 'numbers' brings to the forefront a kind of "rationality", which, as a technology (cf. "Textual trajectories and on-line disputes: communication, government, and multimodal (dis-/re-) orientation about the pandemic across media screens"), allows for the interpretation of such losses, whilst its naturalising (and militarised) orientation promotes the calibration and operation of a "technology of power" that is biopolitical in its nature (Foucault, [1975-1976] 2003, p. 241; Venn, 2009). From this perspective, that orientation contributes to suppressing a sense of (immediate) governmental responsibility. It would ideally encompass the social, and here that would involve, for example, the political, ethical and affective/empathic dimensions. 


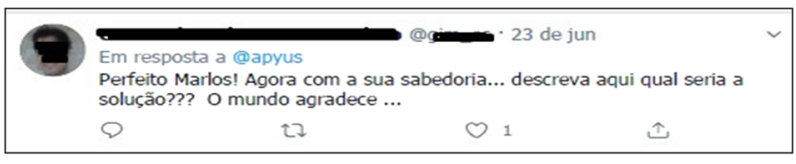

Fig. 8 A Bolsonarian co-framer defying the journalistic discourse.

Translation: Perfect Marlos! Now with your wisdom...describe here what would the solution be??? The world thanks you... .

The disputes that gravitate around the meaning of death in this panorama and the way that the clashes referred to take place have an impact on how the dead bodies in Brazil may be seen, at first, from a naturalising perspective. It seems that such bodies can be initially apprehended as 'containers' of individuals who would be biologically reduced and biopolitically framed simply as breathing/living 'organisms', because their potential sociopolitical relevance, capable of humanising them, is not a priori given/ recognised.

The recognition of such 'containers' and 'organisms'(or of the trajectory that they might have left behind, in case they die from Covid-19) depends on how social and political relations materialise through selective frames and power operations that dispute such recognition in the domain of the transmedia order of discourse (Butler, 2010, p. 1; Souza Júnior, 2020, pp. 42-52). In this way, elements which may become associated with the process of recognising the locals who die are, for instance, the right to be mourned (not always possible due to anti-Covid protocols) along with the recognition of a sense of trajectory, humanity and citizenship. Bolsonaro's government does not seem to consider beforehand that implied sense of recognition, which seems to be selectively performed and communicated.

As it stands, Bolsonaro's reply makes visible a potential zone of recognition during the pandemic, where the trajectory of dead bodies in Brazil and their association with the elements referred to may be selectively (dis-)regarded, as an effect of that technology of power. Such a technology becomes visible whilst Bolsonaro's government is communicated, contributing at once to exposing its biopolitical effects and regulating (through the media domain) how those dead bodies (and particularly the ones framed as 'alien' to the Bolsonarian network) or their deaths may be naturalised and/or neglected across a network of media screens. In this sense, the notions of 'body' and 'population' point to those who are affected by Covid-19 and die from it under the ruling of Bolsonaro's government. Those notions, here, become interconnected. They are inscribed in a governmental configuration that is operated both as a disciplinary and a regulatory technology through framing performances.

Through digital repetition and circulation, that technology collaborates to pulverise the responsiveness to the death of each individual Other, whose loss deserves to be lamented, or whose existential trajectory (or potential interrupted bonds) need to be remembered. This pulverisation may be developed because, from the perspective of the biopolitical technology, the latter: “ (...) exists on a different scale (...) [this] power is applied not to manas-body but to the living man (...) to man as species (...) [this] technology is addressed to a multiplicity of men (...) to the extent that they form (...) [and may be conceived as] a global mass (Foucault, [1975-1976] 2003, p. 242; italics mine).

At this point, it is necessary to take into account the biopolitical potential that affects how responsiveness may emerge and be directed towards the death of the Other across a network of media screens during the Covid-19 crisis. It then becomes important to discuss the following issue: how social media users', through their (re-/co-)framing performances and repertoires of (re-)interpretation, (dis-)regard not only Bolsonaro's governmental responsibility, but also the Covid-related deaths which

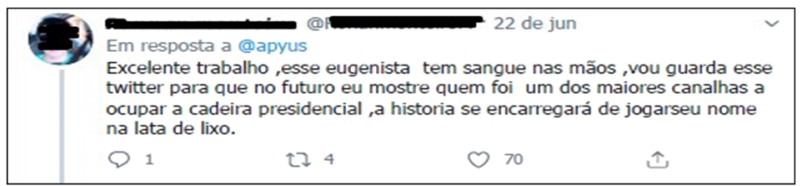

Fig. 9 A re-framer producing a complex reinterpretation of the Covid-19 crisis. Translation: Excellent job, this eugenicist has blood in his hands, I will save this twitter [sic] so that in the future I can show who was one of the biggest bastards to sit on the presidential chair, history will play its part and throw his name into its dustbin.

emerge under the ruling of such a government during the pandemic? I will address that issue through Figs. 8 and 9.

In Fig. 8, we see that a co-framer replies to the journalist who has created the thread. I understand that the Twitter user frames the thread as a 'problem', when I take into account the following excerpt: "describe here what would the solution be???" Framing the thread through this kind of interpretive orientation throws light on a particular communicational strategy that the Bolsonarian network may resort to, when they have to deal with circulated information which may be framed as 'problematic' or 'unfavourable'.

In doing so, Bolsonarian co-framers can delegitimise interlocutors, by discursively taking as new 'targets' those the Bolsonarian network may frame, for example, as: (i) 'vulnerable' (they do not even seem to 'qualify' as interlocutors, and may be framed through ad hominem strategies - see the use of cursing in Fig. 2); or (ii) 'competitors' (interlocutors whose communicational performances and/or 'authority' may be seen as a 'threat' to the consolidation of Bolsonarian beliefs and/or conducts). Moreover, their targets may become expert discursive fields and their complex issues/topics. Those may be addressed through textual purification (Souza Júnior, 2020, p. 89). It can contribute to invisibilising such issues/topics or selectively 'hygienising' and communicating them as 'less problematic' contents, whilst, discursively, configurations marked by inequities (e.g. situations where we can perceive lack of [social] justice or fairness) are also sustained as an effect of such purification. By considering that inequities may be sustained along with their 'silent salience', I was led to conceive of textual purification as a discursive-semiotic strategy that would not be understood as equivalent to what in figurative language we call euphemism.

When this strategy and its selective framing orientation is cooperated (since it makes visible the same sense of deviation from a topic that was present in Bolsonaro's reply), at least two important effects can be observed in Fig. 8. Firstly, the separation between Bolsonaro's government and governmental responsibility that seems to be sustained as a belief by this Bolsonarian coframer. As we can see, in an ironical way (i.e. "Perfect Marlos! Now with your wisdom..."), this participant's performance operates through a frame of textual purification, whose semiotic work produces an 'interactional boomerang'. The latter discursively redirects such a responsibility (in an unfair way) to the thread designer, asking him a solution for the 'problems' that the thread was exposing. The simplification and the minimisation of the complexity of such issues become visible here, since the journalist's capacities/social role (ideally: collect and/or check information/report/inform) and the types of responsibility mentioned earlier belong to different discursive fields, which demand different attributions/actors. At this point, the journalist seems to be challenged as a competitor.

Secondly, with the emergence of this discursive 'redistribution' of responsibility, the Twitter user does not seem to hold Bolsonaro's administration accountable in any way for the 'problems' communicated by the journalistic thread. This co-framer, then, seems to 
sustain the relevant and silent biopolitical separation between locals' Covid-related deaths and governmental responsibility. In sum, this post projects: (i) a sense of disregard in relation to the pandemic as an event that is framed as 'problematic', once such an event may become more complex and affect the governmental 'authority' of Bolsonaro's administration; and (ii) a complete indifference to the growing multiplication of deaths, which may be framed as a central 'problem'-and that seems to be selectively invisibilised by the Bolsonarian network.

If, on one hand, co-framers may develop framing dynamics which neglect that multiplication or dissociate such losses from the domain of collective and governmental responsibilities, on the other, re-framers inaugurate textual disputes that can disrupt this scenario of textual purification. Figure 9, will point to the configuration of disruption through which discursive hybridity and more complex re-framings emerge.

In Fig. 9, the Twitter user emerges as a re-framer and makes visible a discursive arena, where the perspective that projected the delegitimisation of the field of journalism in Fig. 8 becomes disputed. This dispute points to at least two relevant aspects, which seem to affect and expose the Bolsonarian framing performances and strategies: (i) the different kinds of 'responsibility' at play during the Covid-19 crisis; and (ii) responsibilisation itself and how it reconnects the domain of government to Covid-related deaths in Brazil.

The first aspect is perceived when the re-framer in Fig. 9 reasserts the discursive authority of professional journalism during the pandemic (i.e. "Excellent job [...]"). This aspect also contributes to giving visibility to journalistic responsibility and its social relevance. That reverberated relevance can help us understand why the field of journalism seems to be taken as a competitor or target of delegitimisation through the performances of co-framers and indeed why that Bolsonarian strategy seems to be important to such participants. It collaborates to affect the material conditions which pave the way to the interinstitutional forging and textual communication of the notion of journalistic fact/'truth' (Foucault, [1970] 1981, p. 55). Such a notion emerges from interconnexions that, more specifically, involve Covid-19 records (i.e. cases and deaths), governmental performances, the dimensions of journalism, medical science and history in the context of the pandemic. In this regard, a sense of trajectory associated with a genealogical modulation is indirectly promoted by the legitimised journalistic thread, which gives visibility to a repertoire of reinterpretation in Fig. 9.

The second aspect 'converses' with the previous one and becomes visible through the sign "eugenicist ${ }^{23}$ "- used to re-frame Bolsonaro. The repertoire of reinterpretation that the participant in Fig. 9 mobilises through this classification makes visible an interconnexion that points to the dimension of history. Reoriented by that dimension, the re-framer introduces the domain of historical responsibility as a constitutive domain of the abovementioned kinds of responsibility. Being associated with those combined dimensions of responsibility, the performance of the Twitter user in Fig. 9 amplifies its framing potential. Such potential suggests that, whilst the participant reinterprets Bolsonaro as a "eugenicist", a set of interconnected and (in-) visible elements that gravitate around this classification become part of this framing amplification. Thus, it is necessary to take a close look at this emergent process of reinterpretation, in order to discuss the Brazilian pandemic scenario, its sociohistorical and governmental configurations, considering, at the same time, the "eugenicist"/biopolitical orientation that seems to have triggered the dynamics of reinterpretation under discussion.

The first reinterpreted element points to the relation between Bolsonaro's administration, the virus and the pandemic itself.
More specifically, the historical perspective projected through the reinterpretation of the re-framer suggests that Bolsonaro's "eugenicist" power exercise takes the virus as an 'ally' (but no longer to blame, as we have already seen in the section "Frames, textual disputes related to the Covid-19 virus and their effects"). Through this reframing dynamics, the 'ally' would reveal a 'novel' feature: its biopolitical collaboration with the "eugenicist" government, because the virus would be performing a cleansing task, by generating the multiplication of infections and deaths. In turn, such a hybrid biopolitical network (which would inter-relate the disease and Brazil's federal administration) seems to be traced by the re-framer. It suggests that the sociohistorical perspective projected by the participant in Fig. 9 associates the development of the pandemic with its 'weaponisation', which the "eugenicist" government would be making active, for instance, through replicated conducts amongst its own people. Thus, if the pandemic can be reinterpreted as a weaponised biopolitical configuration, the recognition of a "eugenicist" government points to a configuration where political power would be exerted "to expose [...] its own citizens to the risk of death" (Foucault, [1975-1976] 2003, p. 245).

The second element brings into the spotlight the relation between those replicated conducts, the potential that ill bodies develop to 'freely' co-exist in the Brazilian panorama as biopolitical 'weapons', and the eventual biopolitical separation ${ }^{24}$ between such bodies and Bolsonaro's government. That separation may suddenly emerge (as every fatality takes place), exposing situations where deaths can be disregarded and/or invisibilised. In this way, such co-existence materialises through the emergence of bodies who might have been exposed to the disease but are 'free' to circulate amongst the rest of the local population. This materialisation would forge a context marked by weaponisation. The latter could be reinforced by the conducts that the "eugenicist" government would be promoting, for example, if we think about this issue and keep in mind the street demonstrations, which seemed to 'compete' with anti-Covid efforts (cf. "Framing disputes involving bodies, social spaces and strategies of prevention"). Based on Foucault (1982, p. 790), it is possible to understand that demonstrations communicate a message of 'liberty' through the performance of bodies who occupy the streets. These events may also communicate, as an effect of such performances, a selective sense of vivacity and a projected 'normalcy'.

When the performances motivated by 'liberty' eventually generate ill and dead bodies, they contribute to hierarchising 'life' as if 'liberty' were superior or more valuable than the former. With this scenario, governmental, collective and historical responsibilities may emerge as demands. Preventing the emergence of such demands (or, in other words, making a sense of 'pressure for responsibilisation' into an obstacle that would affect the domain of government) can contribute to ensuring pandemic losses are selectively disregarded. As it stands, the value that such 'free' locals 'acquire' seems to be circumstantial, whereas the same 'free' individuals replicate conducts that can expose themselves to the risks of the virus. Hence, such exposed participants may enter a biopolitical dimension that would be operated by the "eugenicist" government. This operation would become visible through the emergence of the death-function, once the latter 'eliminates' the prevalence of pastoral power that can govern the conducts of the living (Foucault, 1982, p. 784, 790).

So, that biopolitical dimension would operate an intervention that neither focuses on individual deaths/individual beings, nor on their individual trajectories. That focus would be on the multiplication of death rates, which would become a 'problem' for the Bolsonarian administration in what concerns, for 
instance, the field of economy and its 'neoliberal' orientation (cf. section "Preliminary associations: the Covid-19 pandemic, journalism and two related presidential repertoires of communication"). In that way, such an intervention (which, for example, contributes to 'authorising' the discursive prevalence of the field of economy and its neoliberal 'freedoms'/priorities over the medical-scientific anti-Covid efforts) would be guided by one of its biopolitical intrinsic principles, that is to say: "[...] the gradual disqualification of death" (Foucault, [1975-1976] 2003, p. 247). In addition, Venn (2009) observes that securitisation, as a form of rationality which can be linked to such a disqualification, genealogically makes visible its association with colonialism, biopower and neoliberalism.

In turn, these genealogical reverberations, locally, contribute to constituting economy as a relatively 'autonomous' field that can (re-)forge its own 'freedoms', by, nonetheless, frequently imposing 'barriers' upon other domains. Especially when economy can justify its own 'priorities' and practices, for instance, based on notions of rationality and "production" (Foucault, [1970]1981, p. 55), the restrictions operated by the field of economy may emerge oriented by the neoliberal "audit culture". It can be understood as a domain of biopolitical power responsible for generating operations/practices that generalise and praise calculability, or as a set of resources that prioritise "quantitative rather than qualitative measures of value, $[\ldots]$ driven by similar concerns with control, circulation and security, now expressed in terms of money as the fundamental and ultimate value" (Venn, 2009, p. 219).

From this perspective, the biopolitical configuration of the "eugenicist" government would be linked to the local prevalence of neoliberalism and securitisation, which can produce a rationality responsible for generating a zone of disregard. That zone, oriented by such a prevalence, may contribute to selectively separating the dimension of government from its responsibilities in relation to all locals who have died from/with Covid-19, if we consider that "[Pastoral] Power has no control over death, but [biopolitical power] [...] can control mortality" (Foucault, [1975-1976]2003, pp. 247-248). This schism or separation would emerge as an effect of that rationality, which economy in its relatively 'autonomous' operation (driven by selectivity) may 'offer' to the domain of government. Economy, then, collaborates to 'equip' that domain (guided by pastoral power) with the 'rational' biopolitical instrument referred to. As Foucault points out to us, below, the biopolitical justification for the emergence of such a governmental schism can be understood as follows:

Once the State functions in the biopower mode, racism alone can justify the murderous function of the State[...]If the power of normalisation wished to exercise the old sovereign right to kill, it must become racist[...]When I say "killing" [it is not simply] murder as such, but also every form of indirect murder[...] exposing someone to death, increasing the risk of death for some people [...]this is something much deeper[...] a mechanism that allows biopower to work[...] [The] State[...]is obliged to use race, the elimination of races and the purification of the race, to exercise its sovereign power[...] the actual roots of racism $[\ldots]$ most murderous States are also[...]racist $[\ldots]$ take the example of Nazism[...]the power of life and death, was granted not only to the State, but to a whole series of individuals $[\ldots]$ everyone in the Nazi State had the power of life and death over his or her neighbours murderous power [...]not simply a basic political objective or a means, but a sort of ultimate and decisive phase in all political processes [...] (Foucault, [1975-1976]2003, pp. 256-259).

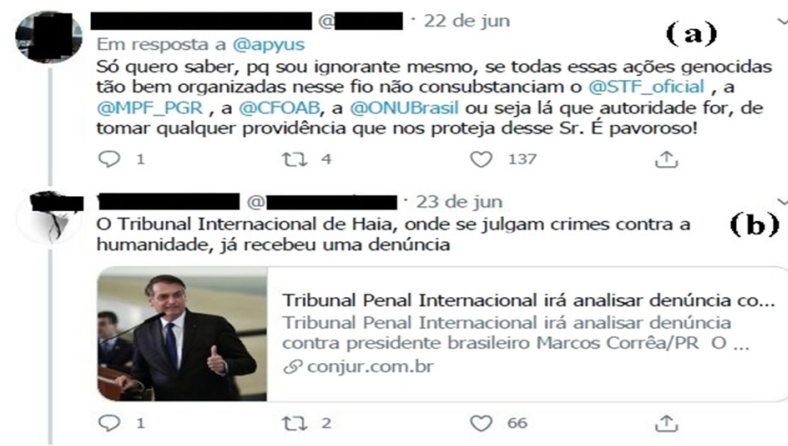

Fig. 10 Re-framers co-constructing perspectives regarding Bolsonaro's government and responsibilisation. Translation (a): I just want to know, because I'm really ignorant, if all those genocidal actions so well-organised in this thread cannot serve as basis for institutions such as @STF_oficial, @MPF_PGR,@CFOAB, @ONUBrasil or any other [public] authority to take measures that protect us from this gentleman. It's appalling! Translation (b): The International Court for Justice in the Hague, where crimes against humanity are judged, has already filed a complaint ${ }^{26}$.

As the reframing in Fig. 9 has promoted a perspective that amplified the possibilities of reinterpreting Bolsonaro's government, for instance, as "eugenicist", the Twitter thread has turned into a transmedia space where that potential for communicational amplification has increased. It has contributed to making visible additional performances of re-framers. Such performances have emerged based on epistemic co-constructions, which collaborated to expand reinterpretations. Next, Fig. 10 shows a framing dynamics that has been captured and exemplifies how those coconstructions may occur.

In Fig. 10A, we can see that the space of the journalistic thread has contributed to generating a performance of reinterpretation that, little by little, produced frames with more specific claims. Here, "eugenicist" as a framing classification is substituted by "genocidal" 77 . The participant in Fig. 10a, then, urges several institutions to take action against a president who seems to be conceived as a criminal by his own people. It is in this sense that the contribution of the re-framer in Fig. 10b not only co-constructs and appears to sustain that framing of criminalisation, but also amplifies the repertoire of reinterpretation of re-framers. Digital co-constructions and corroborations collaborate, then, to make visible the emergence of 'media courts'. Such courts can produce amplifications via (re-)framing dynamics that, as suggested in Fig. 10, may connect in a transdimensional way virtual/'digital courts' to those that are physical/in the 'offline world', through the configuration of the transmedia order of discourse.

Discursively, then, that amplification projects a hybrid sense of juridico-historical responsibilisation, which, after the abovementioned criminalisation, is now neither confined to the domain of the 'non-authorised'/lay citizens, nor to that of the local authorities. Here, a sense of trajectory expansion has redirected the reported event, its participants and effects to the international sphere of "crimes against humanity". This broadened and more complex panorama of reinterpretation seems to have contributed to attracting more re-framers to the discursive arena of the thread, making it very much harder for co-framers to sustain performances of textual purification, what would allow them dispute or interfere with re-framer's communicational dynamics. Those dynamics have amplified the debates regarding the relation between government, death, responsibilities in the context of the Covid-19 crisis and its (bio-/geo-) political effects, which have become (in-)visible through the process of transmediatisation. 


\section{A few (in-)conclusive remarks}

As I seek to finalise this section, the pandemic does not appear to be levelling off in the Brazilian panorama. If we consider that panorama along with all its discursive and transmedia repercussions, trying to conclude or explain anything in an exhaustive way about such repercussions would be very much like assigning to oneself a Sisyphean task. So, to remind the reader that the trajectory of the corona crisis in Brazil 'goes on', based on a genealogical perspective, I avoid using the term 'conclusion' in this paper. In this direction, I will not simply present the key points of the trajectory that I have made visible. I will also point to potential reflexions and follow-up discussions, which can be envisioned or fostered as part of the constitution of the researcher's ethos, as I understand it from a critical perspective (cf. Foucault, 1982, p. 778).

The Covid-19 crisis has been framed as a complex social event in this paper. Its (bio-/geo-)political effects still seem to resonate throughout the world in different ways. Now, it is important, I think, to point to two examples of relatively recent effects that have to do with the trajectory discussed here. Firstly, Donald Trump's US presidential campaign and his defeat to the Democrats, Joe Biden and Kamala Harris, whilst most voters seem to have sanctioned Trump for his handling of the pandemic, as many polls ${ }^{28}$ had been suggesting during that period. Secondly, the emergence of international efforts focussing on Covid vaccines vis-à-vis Bolsonaro's claim of "victory ${ }^{29 "}$, after vaccine trials have been halted in Brazil, which, sadly, continues to be the second country with most deaths after the US, despite the situation of underreporting (cf. section "Preliminary associations: the Covid-19 pandemic, journalism and two related presidential repertoires of communication"). Brazil is likely to surpass 500,000 Covid-related losses by July $2021^{30}$, whilst Bolsonaro's administration (apparently) is not yet convinced of the necessity of national lockdowns as an anti-Covid strategy. This scenario has led the Brazilian congress to begin an enquiry into Bolsonaro's administration responses to Covid-19. The enquiry could pave the way to impeach Bolsonaro or have an impact on his potential re-election campaign. The effects referred to still appear to be related to the set of interconnected elements that I have presented in the section "Corpus and methodological approach", namely: (i) the Covid-19 virus; (ii) bodies, social spaces and strategies of prevention; and (iii) deaths, government, rationality and the population in Brazil. As it stands, the perceived persistence reverberated by such aspects justifies the relevance of exploring and discussing the interconnexions that have emerged and related to such elements.

To explore and discuss those elements, considering a corpus of 11 multimodal posts and their projected interconnexions, I have resorted to the oligoptic approach and to Foucauldian conceptions. In doing so, I kept in mind the concept of transmedia order of discourse and the following transdisciplinary questions/ reflexions:

i. How is the corona crisis being framed and communicated in Brazil?;

ii. What are the roles of the different media spaces in this communicational process?;

iii. How can communication and (re-)framings be understood in that context of crisis?;

iv. What kinds of text, participant and repertoire of (re-) interpretation emerge through circulation?;

v. What/who is (re-)framed, how meanings emerge and what becomes (in-)visible in this process?

In turn, I have sought to generate intelligibility about the transmediatisation of the Covid-19 crisis in the Brazilian panorama, considering some of the perspectives that have emerged.
The circulation of those perspectives has contributed to giving visibility to (bio-/geo-)political repertoires of interpretation. Through such repertoires, firstly, power and government have been operated in a distributed way, reverberating with the emergence of a network of co-framers, governmentality, digital/ media practices and conducts which have been connected to offline performances. In response to that reverberation, we have seen that reframing practices emerged as dynamics of resistance.

In the first stage of the trajectory that I have discussed, governmentality became visible, for example, when the Bolsonarian network forged repertoires of interpretation and government to deal with the communication of the disease. Oriented by Bolsonaro's recalcitrant framing performances, which proposed to understand the disease as a "little flu", we have seen that a biopolitical repertoire of interpretation has been disseminated and, firstly, promoted a belief that disregarded the lethal potential of the virus, delegitimising the discursive authority of the medicalscientific domain. Secondly, projecting connectivity with the domain of conspiracy theories and religion, the expression "Chinese plague" has emerged as a memetic tool of soft power. Through it, Donald Trump has forged a repertoire of communication which framed China and successfully influenced Bolsonaro's administration as well as part of the local population to interpret that country in at least two ways: (i) geopolitically and (ii) biopolitically. In this way, we have seen that, whilst the CT related to the "Chinese plague" circulated, the Covid-19 virus was not exclusively seen through the medical-scientific lenses, as an element that would demand anti-Covid efforts. Instead, the virus seemed to be taken as an 'ally'. As an emergent instrument of soft power, the memetic expression and the (bio-/geo-)political repertoires of interpretation that have been mobilised generated a CT that, as an effect, helped to blame and facilitated punishment.

In response, dynamics of resistance have emerged through the media practices of the network of re-framers, who have been responsible for redirecting the virus to the medical-scientific domain, legitimising its discursive authority. Re-framers, then, highlighted the importance of legitimising 'science' (here, exclusively associated to the field of medical discourse). They focussed on exposing, firstly, biopolitical and selective dynamics of invisibilisation, which have been operated not only through the mobilisation of terms like "little flu", but also through the association involving Bolsonaro's administration, Brazilian Army's officers and their support in legitimatising a purported effectiveness of Hydroxychlroroquine to cure Covid-19. Secondly, reframers have exposed the operation of geopolitical dislocations, which were discursively produced through the use of the expression "Chinese plague". Instead of selectively (de-)limiting the scope of their framing focus, re-framers' dynamics have made visible, on one hand, the co-construction of discursive 'authority' as a process and its association with hybridity. The latter pointed to interconnexions that involved, for instance, the field of journalism, the juridical and medical-scientific domains. On the other, the network of re-framers has contributed to generating discursive expansions and these, in turn, gave visibility to biopolitical implications (e.g. the association of Covid-related deaths with the dimensions of governmental and juridical responsibility).

If in the first stage of the trajectory co-framers and their related network seemed to have framed the virus as an 'ally'; in the second stage, they have collaborated to make the rest of the population see social distancing and anti-Covid efforts in general as 'obstacles' in the pandemic scenario of Brazil. Operating a kind of multimodal 'authorisation' to the delegitimisation of antiCovid efforts, a bodily communicated infra-norm (at times, indirectly amplified by professional journalism) has contributed to discursively promoting a 'dialogue' between crisis and conflict 
in this pandemic panorama. The latter has pointed to the emergence of Bolsonaro's body as a 'message', communicated through a biopolitical repertoire of interpretation, which could be translated and disseminated as an anti-Covid armour/'costume' across a network of media screens. A belief in such an imagined armour (almost a mythological one) seems to have contributed to the emergence of corporeal performances associated with 'patriotic' street demonstrations, in which the Bolsonarian network took part and claimed to defend 'liberty' and 'democracy'. Through such repeated rituals and conducts, that network has promoted rituals of pandemic denial through techno-preacherism and made visible epistemic disputes through which the 'authority' of the medical-scientific discourse has been defied. In addition, their repertoire of interpretation contested the authority of governors, mayors as well as the Brazilian State itself. More specifically, that kind of contestation has been directed to the Brazilian Supreme Court's Constitutional prerogatives, whilst co-framers seemed to exempt the Executive Power (i.e. Bolsonaro's administration) from its co-ordinating responsibilities in relation to the (mis-)handling of the pandemic.

Presenting divergent perspectives when considering such responsibilities, re-framers and their co-constructed network have made visible discursive modulations and a biopolitical repertoire of reinterpretation that re-framed the role of Bolsonaro's body (more specifically the role of his presence) in the streets during the pandemic. In this direction, we have seen that re-framers critically renegotiated how meanings circulated across their own network. Through this relational process of renegotiation, the contributions between non-authorised social media users and professional journalism allowed for situated episodes of epistemic collaboration and, as an effect, these contributed to expanding the repertoire of reinterpretation that re-framers have mobilised. After giving visibility to that expansion, re-framers have problematised the governmental performance of Bolsonaro as a presidential "sabotage" against anti-Covid efforts. These participants have forged a discursive arena which socio-technically pointed to the interconnexion between bodies, media screens, social spaces and a scenario of multimodal (dis-)orientation and (dis-)legitimisation of anti-Covid efforts. As we have seen in the second stage, the 'architecture' of this socio-technical configuration gave visibility to this arena in which co-framers and reframers disputed how the street demonstrations referred to, their related performances (framed as sources of "bad examples") and claims were (de-)legitimised in the pandemic panorama under discussion.

In the final stage of our trajectory, that architecture and its associated arena have become more expanded and exposed. The following interconnect elements have contributed to that expansion: (i) the growing number of deaths amongst the population in Brazil and (ii) governmental responsibility and how the performances related to it have been (re-)framed through biopolitical repertoires of (re-)interpretation. Those elements have shown that Bolsonaro's biopolitical repertoire of interpretation emerged in association with a particular kind of rationality that militarises and praises quantification (i.e. death rates, rather than individual deaths). That rationality, on one hand, collaborated to disconnect Covid-related deaths from governmental responsibility, ethics and/or empathy; dehumanising, as an effect, locals who had passed away. On the other, professional journalism seemed to counter that governmental performance of dehumanisation, exposing through a re-framing of resistance a sense of 'deviation from the presidential responsibilities' that Bolsonaro has made visible with his reply (i.e. "I am not a grave-digger, okay?"). When the journalistic biopolitical repertoire of reinterpretation collided with the biopolitical repertoire that oriented the Bolsonarian network, journalism re-forged itself as an authorised domain of power-knowledge. That collision has contributed to affecting the dimension of government, making visible how the Bolsonarian repertoire of interpretation may selectively (dis-)regard or naturalise the Covid-related deaths of locals, as an effect of that biopolitical rationality or technology of power.

The forging of such repertoires of (re-)interpretation has had an impact on how co-framers and re-framers, respectively, sought to contain the repercussions or expose the implications related to the growing number of deaths. Textual and epistemic disputes have become intensified through the transmedia order of discourse, pointing to how such repercussions and implications have been communicated across a network of media screens.

When confronted with such 'unfavourable' atmosphere of communication (that can undermine the governmental authority of Bolsonaro's administration during the Covid crisis), the network of co-framers seemed to work to purify that atmosphere, by redirecting the responsibility for the 'problem' (i.e. the growing number of deaths) to those who had made explicit that the 'problem' existed (i.e. professional journalism). In this way, the Bolsonarian network has targeted those who they seemed to interpret as competitors (i.e. journalists) and contested the legitimisation of the discursive authority of such messengers, rather than paying attention to their message (or that communicated 'problem'). When we take into account this dynamics of the Bolsonarian network, it becomes visible how their biopolitical repertoire of interpretation has been operated here. It has contributed to selectively minimising, purifying and containing an 'unfavourable' atmosphere of communication, whose repercussions derived governmental and biopolitical implications across a network of media screens.

Throughout our journey, we could see that the media practices of the Bolsonarian network have been characterised by framing dynamics which neglected the multiplication of deaths or dissociated such losses from the domain of collective and governmental responsibilities. Conversely, the network of re-framers has produced framing dynamics of resistance that could disrupt this scenario of textual purification. In turn, re-framers have not only reasserted the discursive authority of professional journalism and the importance of journalistic responsibility, but also associated their framing dynamics with the domain of historical responsibility. That domain has become particularly visible when the network of re-framers used the sign "eugenicist" to reinterpret Bolsonaro's administration during the pandemic, pointing to how Bolsonaro's government seemed to constitute a network that inter-related the Executive Power and the virus as 'allies'.

This 'alliance' would project a scenario of weaponisation of the pandemic, where, for example, "eugenicist" conducts, as an infranorm, would have contributed to orienting the Bolsonarian network towards a message of 'liberty', a selective sense of vivacity and normalcy. That message has mobilised potential ill bodies, that would have become 'free' bodies, and then, governmental weapons, capable of disseminating the coronavirus. So, when a reframer projected this panorama of weaponisation, indirectly perceived through the use of the term "eugenicist", their network seemed to have taken into account different types of responsibility. More precisely, governmental, collective and historical responsibilities have emerged as demands. The explicit use of "eugenicist" and the emergence of those demands have projected an interconnexion that gave visibility to a governmental configuration which the "eugenicist" government would be operating under the directions of the death-function. Locating the latter helps us to understand how that function would orient the Bolsonarian network, interconnecting their militarised repertoire of interpretation with a biopolitical zone of disregard that can disqualify the death of locals and produce schisms during the corona crisis. In the case of Brazil, this disqualification emerges as an 
effect of a configuration that genealogically points to the interconnexion between militarism, colonialism, schisms, biopower, neoliberalism and securitisation.

Furthermore, we could see that the network of re-framers have generated performances of reinterpretation that, gradually, produced more epistemic collaboration, making visible more specific claims. In this regard, we have seen the term "eugenicist" being substituted by "genocidal". This dynamics of framing amplification suggests that the Brazilian president has been conceived as a criminal by his own people. That amplification has emerged as an effect of digital co-constructions and transdimensional corroborations that gave visibility to 'media courts'. The latter have projected an interconnexion between juridical and historical responsibilisation, making the separation between local and global spheres more difficult to pinpoint, as that interconnexion has brought to the fore the dimension of "crimes against humanity". This complex biopolitical repertoire of reinterpretation that re-framers have forged has contributed to making less visible the dynamics of textual purification of the network of co-framers. With the apparent neutralisation of that network in the space of the thread, re-framers seemed to be more active in it, forging a collaborative space that communicated and sustained an expanding process of denunciation, regarding the relation between government, death and responsibilities in the context of the Covid-19 crisis.

Considering this panorama, I think it is important to stress that 'government' has been reinterpreted through a specific focus in this paper. I have chosen not to resort to the concept of populism (cf. Maly, 2018; Wodak, 2015), which is often mobilised to label the governments of Trump and Bolsonaro. Here, I have not only avoided such a label or a "supposition of a fundamental power" (Foucault, 1982, p. 788), but also tried to focus on what seemed to be overlooked or 'forgotten': local and translocal interconnexions that would point to how the dimension of government catalyses power operations by, for example, (re-)forging conducts through (re-)framing performances in a networked and hybrid (i.e. pastoral and biopolitical) way. As it shows, we deal with further problematisations when we choose to discuss government and power from a genealogical and transdisciplinary perspective. For this, I have traced associations between those presidential repertoires of communication. It allowed me to discuss how such repertoires seemed to be administered and the kinds of relation they develop based on hybridity. Hybridity appears to exert some influence over those repertoires, leading them to give room to a domain of complementation that can be associated with the operation of framing dynamics, media strategies and techno-preacherism.

Ultimately, the genealogical perspective developed in this paper points out that religion and the State ${ }^{31}$ (to some extent) seem to be reuniting in certain 'Western democratic' panoramas, where intercultural and hybrid governmental performances have been exposing the complexity of the Covid-19 pandemic as a sociohistorical event. Those performances connect with a stark religious/pastoral component that later can be recycled in unpredictable ways by the dimension of government and/or administrations, generating, for instance, 'civilisational' disruptions that may affect what used to be viewed as sustained conventions. This scenario of disruption can collaborate to (re-)forge infra-norms that justify certain governments' administrative (de-) limitations, whereas anti-science stances/policies may be promoted and/or adopted by those administrations. In the local panorama, such governmental performances, stances and (bio-/ geo-) political effects become visible through a network of media screens. Through the latter, we may witness citizens and their citizenship undergoing transdimensional transformations. Such subjects (and their networks) may refuse to abandon the 'on-line' world's beliefs to which they have been exposed and relinquish their local 'offline' Constitutional rights to life and health. In this way, those citizens can make visible epistemic conflicts and disruptions through which they reject, for instance, the Covid-19 vaccines made by China and Russia. Circulated infra-norms have been contributing to framing those as "communist" 32 products.

\section{Data availability}

The dataset of public comments and replies that I have discussed is available at https://twitter.com/apyus/status/127521833035 0206976 .

Received: 22 January 2021; Accepted: 13 August 2021; Published online: 13 September 2021

\section{Notes}

1 See https://www.bbc.com/news/world-51839944 Accessed 1 Jul 2020.

2 See https://www.reuters.com/article/us-china-health-brazil/brazil-test-confirms-firstcoronavirus-case-in-latin-america-source-idUSKCN20K1EU. Accessed 21 Jun 2020

3 See https://www.reuters.com/article/us-health-coronavirus-brazil-cases/brazil-likelyhas-12-times-more-coronavirus-cases-than-official-count-study-findsidUSKCN21V1X1. Accessed 21 Jun 2020.

4 See https://www.theguardian.com/world/2020/jun/09/judge-orders-bolsonaro-toresume-publishing-brazil-COVID-19-data. Accessed 21 Jun 2020.

5 At the time, Eduardo Pazuello, a Brazilian Army's general who would allegedly have a background in logistics, became the interim minister. Later, Bolsonaro would confirm him as Minister of Health. Pazuello has substituted two other civilian medical doctors (i.e. Mandetta and Teich).

6 See https://www1.folha.uol.com.br/internacional/en/scienceandhealth/2020/06/newsorganizations-team-up-to-provide-transparency-to-COVID-19-

data.shtml?utm_source $=$ newsletter\&utm_medium $=$ email\&utm_campaign $=$ new wsen. Accessed 21 Jun 2020.

7 On 28 April, 2020, The United States was the first country to confirm that amount of cases. See https://edition.cnn.com/2020/04/28/health/us-coronavirus-tuesday/ index.html. Accessed 21 Jun 2020

8 My specific uses of the parentheses: (i) to indicate two possibilities of reading a term, like in (in-)visible and (ii) to present actions or effects that point to a dispute, such as in: "capable of (des-/re-)organising networks".

9 For some, it can also be a 'discourse of war' against the virus or 'the invisible enemy' Cf. https://www.theguardian.com/world/2020/mar/03/coronavirus-south-koreadeclares-war-on-outbreak-as-who-experts-arrive-in-iran. Accessed 27 Jun 2020

10 The aforementioned 'conservative' agenda and the neo-pentecostal segment are locally convergent. Participants in this configuration have been intuitively named "gado" (i.e. cattle) by those who do not support Bolsonaro's government. This convergence contributes to defining or sustaining the communicational strategies of Bolsonaro's government(-ality), playing an important part in the hybrid statereligious-pastoral and algorithmic replication of the conducts that circulate through a kind of 'techno-preacherism' amongst Bolsonarian social media users. This suggests that, as an effect of pastoral power, a large part of the 'gado' may see in Bolsonaro's messages a presidential 'passport to salvation', which would make them immune or special (to the point that they may selectively deny the existence of the disease or minimise its impacts).

11 The thread and its related public comments/replies are available at https:// twitter.com/apyus/status/1275218330350206976. Accessed 21 Jun 2020.

12 In the original: "Como Jair Bolsonaro tentou sabotar o combate ao corononavírus".

13 For this potential pastoral component, Bolsonaro has already been compared to the North American cult leader Jim Jones. See https://www.salon.com/2020/04/08/is-jairbolsonaro-brazils-right-wing-president-the-new-jim-jones/. Accessed 5 Dec 2020.

14 Chronologically, as Bazzicalupo (2014) reminds us: "Joseph Nye has adopted the term for the first time in the nineties to envisage, in the field of International Relations, some sort of soft power as opposed to the hard military interventionism of American geo-political influence". Alternatively, I am not only reflecting on what one can do with soft power, but also on its effects in that panorama. Thus, I do not seek to redefine soft power.

15 That claim has been dismissed. See https://www.dw.com/en/coronavirus-and-theplague-the-disease-of-viral-conspiracy-theories/a-52700321. Accessed 2 Dec 2020.

16 Additional expressions in that repertoire would be "Chinese virus" or "Kung flu". See https://www.the-sun.com/news/548151/trump-defends-coronavirus-chinese-virusbeijing/. Accessed 2 Dec 2020. Eduardo Bolsonaro (Jair Bolsonaro's son, federal lawmaker-at that time Chair of the Lower House Committee for Foreign Affairs) and Abraham Weintraub (former Bolsonaro's Minister of Education and current World Bank Group Executive Director) have contributed to translating (in a broader 
sense) the Trumpist geopolitical views and locally replicating that repertoire. See https://foreignpolicy.com/2020/05/15/chinas-diplomats-are-going-on-the-offensivein-brazil/. Accessed 2 Dec 2020

17 See https://edition.cnn.com/2020/03/22/world/doomsday-prophets-coronavirusblake/index.html. Accessed 5 Dec 2020.

18 See the same term being mentioned: https://www.msn.com/en-xl/news/other/ presidential-debate-donald-trump-blames-china-plague-for-us-economic-woes/arBB19xWvS. Accessed 5 Dec 2020.

19 The graph is available at https://twitter.com/fmalaco/status/1275440726831063041/ photo/1. Accessed 11 Nov 2020.

20 A crime of responsibility may refer to "[...] the Brazilian equivalent of high crimes and misdemeanours associated with the presidential office. Any Brazilian citizen can accuse the president of this crime". Cf. https://www.dw.com/en/where-could-brazilscriminal-investigation-of-jair-bolsonaro-lead/a-53284984. Accessed 11 Nov 2020.

21 See https://apnews.com/article/66a86e4cccf4e94ea75a8eedd92afeb3. Accessed 6 Dec 2020.

22 As discussed in Fig. 3, at that time, when the Bolsonarian network mentioned "medicine", it often reflected their belief that Chloroquine could cure Covid-19.

23 This issue points to the importance of taking into account racial and social class dimensions as intersectional difference markers, when we reflect on Covid-related deaths and the domain of inequities in the local panorama, as the findings of a study also suggest. See https://www.forbes.com/sites/williamhaseltine/2020/10/27/in-brazilnew-study-shows-the-poor-and-indigenous-suffer-the-most-from-covid-19/. Accessed 4 Dec 2020.

24 A study has shown how the relation between 'liberty' and biopolitical separation seems to haunt Bolsonaro's voters. See https://wwwl.folha.uol.com.br/internacional/ en/scienceandhealth/2020/07/bolsonaros-rhetoric-against-isolation-may-have-killedhis-voters-more-says-study.shtml. Accessed 18 Dec 2020.

25 One example of the presence of such a repertoire and rationality in Bolsonaro's government has put the spotlight on the Minister of Economy, Paulo Guedes (locally framed as a 'Chicago boy' who is fond of the recently contested Chilean Pinochetianneoliberal model), and on one of his collaborators, Solange Vieira, who leads the Superintendence of Private Insurance and has contributed to reforming the country's pensions. A federal epidemiologist has told Viera that "older people would be more likely to die [from Covid-19]" and, in response, she framed it as a "good" configuration, adding, as reported by the epidemiologist, the following: "That will improve our economic performance as it will reduce our pension deficit". See https:// www.ft.com/content/b1d21b6a-0244-11ea-be59-e49b2a136b8d;https:// www.newsweek.com/brazil-government-aide-says-covid-19s-toll-elderly-will-reducepension-deficit-countrys-1506830. Accessed 4 Dec 2020.

26 See https://uniglobalunion.org/sites/default/files/imce/ english_denuncia_presidente_icc_final.pdf. Accessed 1 Dec 2020.

27 Gilmar Mendes, one of the Brazilian Federal Supreme Court's Justice, has already used the term "genocide" to talk about the pandemic in Brazil, whilst he stressed the participation of members of the military in Bolsonaro's government. See https:// www.washingtonpost.com/world/the_americas/as-virus-spreads-bolsonaro-ties-withmilitary-under-strain/2020/07/13/f603a8fc-c53b-11ea-a8258722004e4150_story.html. Accessed 2 Dec 2020.

28 See https://abcnews.go.com/Politics/64-distrust-trump-coronavirus-pandemicapproval-declines-cases/story?id=71779279. Accessed 18 Dec 2020.

29 See https://www.theguardian.com/world/2020/nov/10/jair-bolsonaro-claims-victoryafter-suspension-of-chinese-covid-vaccine-trial. Accessed 18 Dec 2020.

30 See https://www.abc.net.au/news/2021-03-28/worst-may-lie-ahead-for-brazil-incoronavirus-fight/100034244. Accessed 4 May 2020.

31 To what extent (in practice) is this separation still sustained in such panoramas, where the idea of a Secular State would be one of their constitutive (and most importantly) Constitutional principles? That is one route that I will not be able to pursue in this paper, due to space limitations. So, we can conceive this issue as an additional theoretical reflexion (or invitation), depending on how one (re-) interprets that.

32 See https://edition.cnn.com/2020/08/14/americas/brazil-politics-coronavirusvaccines-fight-intl/index.html. Accessed 18 Dec 2020.

\section{References}

Bazzicalupo L (2014) Soft power, editorial. http://www.softpowerjournal.com/ $\mathrm{web} / ? \mathrm{p}=47$. Accessed 20 Jun 2020

Butler J (2010) Frames of war: when is life grievable? Verso, New York

Foucault M [1975-1976]2003 Society must be defended: lectures at the Collège De France. Picador, New York

Foucault M (1982) The subject and power. In: Critical inquiry, vol. 8 (4). The University of Chicago Press, Chicago, pp. 777-795. https://www.jstor.org/ stable/1343197.
Foucault M [1970]1981 The order of discourse. In: Young R (ed) Untying the text: a poststructuralist reader. Routledge and Kegan Paul, Boston

Goffman E [1974]1975 Frame analysis: an essay on the organization of experience. Penguin, Harmondsworth

Jenkins H (2006) Convergence culture: where old and new media collide. New York University Press, New York

Kress G (2015) Semiotic work: applied linguistics and a social semiotic account of multimodality AILA Rev 28:49-71. https://doi.org/10.1075/aila.28.03kre

Latour B (2005) Reassembling the social: an introduction to Actor-NetworkTheory. Oxford University Press, Oxford

Maly I (2018) Algorithmic populism and algorithmic activism. Diggit Mag https:// www.diggitmagazine.com/wiki/algorithmic-populism

Pennycook A (2007) Global Englishes and transcultural flows. Routledge, London, New York

Souza Júnior, J de (2021) Translation, translingual (re-)framings and the transmediatisation of the War in Syria: exploring concepts and network(-ed) (re-) significations [Tradução, (re)enquadramentos translinguais e a transmidiatização da Guerra na Síria: explorando conceitos e (re)significações em rede(s)]. Rev Indiscipl Linguíst Apl 2(1):1-21. https://revistas.ufrj.br/ index.php/rila/article/view/45269

Souza Júnior, J de (2020) \#HumanityWashedAshore-transmediatisation of the War in Syria: (re-)framings, on-line textual disputes and (de-)humanisation [\#HumanityWashedAshore-transmidiatização da Guerra na Síria: (re)enquadramentos, disputas textuais online e des(h)umanização]. Unpublished Thesis [Revised version]. Faculty of Letters, Federal University of Rio de Janeiro

Souza Júnior, J de (2015) "\#InBrazilianPortuguese", memes and phenomena: linguistics and its suggestions to explore digital event propagation Palimpsesto (Rio de Janeiro, On-line) 21:314-328. Accessed 19 Dec 2020

Sunstein CR, Vermeule A (2009) Conspiracy theories: causes and cures. J Political Philos 17:202-227. https://doi.org/10.1111/j.1467-9760.2008.00325.x

Venn C (2009) Neoliberal political economy, biopolitics and colonialism: a transcolonial genealogy of inequality Theory Cult Soc 26(6):206-233. https:// doi.org/10.1177/0263276409352194

Wodak R (2015) Politics of fear: what right-wing populist discourses mean. Sage, London

\section{Acknowledgements}

I would like to thank the Federal University of Rio de Janeiro (UFRJ, Brazil), and more specifically the Interdisciplinary Graduate Studies Programme in Applied Linguistics (PIPGLA/UFRJ) for their support in proving the documentation that has been required during the article submission process. In addition, I am grateful to Mike Baynham (University of Leeds, United Kingdom) for his comments and suggestions, as these have led me to re-frame, reinterpret and expand part of the discussion that I develop in this paper.

\section{Competing interests}

The author declares no competing interests.

\section{Additional information}

Correspondence and requests for materials should be addressed to Jaimede Souza Júnior

Reprints and permission information is available at http://www.nature.com/reprints

Publisher's note Springer Nature remains neutral with regard to jurisdictional claims in published maps and institutional affiliations.

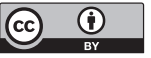

Open Access This article is licensed under a Creative Commons Attribution 4.0 International License, which permits use, sharing, adaptation, distribution and reproduction in any medium or format, as long as you give appropriate credit to the original author(s) and the source, provide a link to the Creative Commons license, and indicate if changes were made. The images or other third party material in this article are included in the article's Creative Commons license, unless indicated otherwise in a credit line to the material. If material is not included in the article's Creative Commons license and your intended use is not permitted by statutory regulation or exceeds the permitted use, you will need to obtain permission directly from the copyright holder. To view a copy of this license, visit http://creativecommons.org/ licenses/by/4.0/

(C) The Author(s) 2021 